\title{
IRREGULAR DISTORTION OF THE ERYTHROCYTES (ACANTHOCYTES, SPUR CELLS) IN SENILE DEMENTIA
}

\author{
H.B. GOODALL" . A.H. REID. D.J. FINDLAY, C. HIND, J. KAY AND G. COGHILL \\ Ninewells Hospital and Medical School, Royal Dundee Liff Hospital and Ashludie Hospital. Dundee. UK.
}

SUMMARY

\begin{abstract}
An excess of irregularly distorted red cells with spiked forms (acanthocytes, spur cells) has been found in a substantial minority of patients with senile dementia of Alzheimer type ( 7 of 50 patients, 3 of 21 men and 4 of 29 women). Of 100 control patients. 42 men and 58 women), 5 ( 3 men and 2 women) showed comparable distortion, but. of these. one man may well have incipient dementia and the others had serious organic diseases which may be associated with comparable erythrocytic changes. The cause of the distortion is not yet clear, but the presence of occasional giant erythrocytes in the absence of general macrocytosis suggests a possible abnormality of cellmembrane synthesis. This distortion may be a useful marker in patients with loss of memory. Whether it is a manifestation of a haemopoietic clone or a constitutional anomaly associated with Alzheimer's disease remains to be seen.
\end{abstract}

KEY WORDS Senile dementia Erythrocytes Acanthocytosis Spur cells Spiked red cells

\section{INTRODUCTION}

This investigation was prompted by the occasional finding of irregularly distorted, spiked erythrocytes in the blood films of patients with progressive dementia of Alzheimer type (Goodall et al. 1991). In 3 such patients the abnormality of the erythrocytes was present for more than a decade and in one of these the blood changes were known to have antedated the dementia by several years. None of these patients showed retinal damage (Bassen and Kornzweig. 1950; Salt et al., 1960) or choreoathetosis (Estes et cl.., 1967; Critchley et al., 1970). The following were excluded as possible causes of the red cell distortion - hypothyroidism (Wardrop and Hutchison, 1969; Horton et al., 1976), hyposplenism, hypolipidaemia (Salt et al., 1960); Herbert et cl., 1983), hyperlipidaemia (especially in alcoholic cirrhosis (Smith et al., 1964), microangiopathic haemolytic anaemia (Brain et (al., 1962), cardiac valve prosthesis, renal damage. Heinz body anaemia, McLeod blood type (Winer et al., 1977; Symmons et cl.., 1979), pyruvate kinase deficiency (Oski et cll. 1964), irreversibly sickled cells and myelodysplasia (Goodall et al., 1991). We therefore decided to examine the blood of patients with established senile dementia of Alzheimer type (S.D.A.T.) to ascertain the frequency of irregularly distorted red cells in such patients.

*Correspondence to: H.B. Goodall. Haematology Laboratory. Ninewells Hospital and Medical School. Dundee, DDI 9SY. UK. 


\section{Patients}

We examined 50 patients ( 21 men and 29 women) with long-established dementia of Alzheimer type. They are either completely hospitalised or attending a day hospital. Their ages range from 58 to 95 , with a mean of 81 years.

\section{Control Patients}

A total of 100 (42 men and 58 women) was examined, 2 for each demented patient and both of the same sex and comparable age (within \pm 5 years of each patient). Otherwise they were unselected. They were taken from the routine screening of the Department of Haematology and included hospital inpatients, outpatients and general practice patients. The majority had normal blood counts. Clinical details will be given only for control patients whose red cells were found to be abnormally shaped or whose history was of interest in relation to the current research. The blood from the control patients was assessed before any clinical information about them was available to the microscopist. That information was obtained from the files of the Department of Haematology, occasionally supplemented by contacting the doctors and other staff involved.

\section{METHODS}

\section{Samples}

Sequestrinised and clotted venous blood was brought without delay to the laboratory and incubated 30 minutes to prevent precipitation of cryoproteins (especially cryofibrinogen) and cold agglutination; both may distort red cells.

\section{Counts}

Sequestrinised samples were counted in a Coulter STKS.

\section{Dry Films}

Three ordinary films and one buffy coat smear from each patient were stained with Romanowsky stain in an Ames Hematek. Films and buffy coats from the two patients with the most distorted red cells were stained with the periodic acid - Schiff technique and Perls/Prussian Blue reaction and reticulocyte preparations made.

\section{Wet Preparations}

$50 \mu \mathrm{l}$ blood were added to $0.95 \mathrm{ml}$. 2\% Bovine Serum Albumin, diluted from $30 \%$ B.S.A. (Behring) in mammalian Ringer solution. The suspension was examined on slides, under coverslips ringed with soft paraffin.

\section{Clotted Samples}

The ABO and Rhesus blood groups were identified in microplates (Bowley et al., 1984) and a Direct Coombs Test was done (Black and Kay, 1986).

\section{Immune Staining for $\beta$-Amyloid Protein}

Immune staining for $\beta$-Amyloid protein used Anti $\beta$-Amyloid (Alzheimer) Antibody (Boehringer Cat. No. 1381431 ) pretreated with formic acid (Roberts et al., 1990). This technique was validated on brain sections from Alzheimer necropsies. 


\section{Assessment of Distortion of Erythrocytes}

Assessment of the shape of red cells is fraught with difficulties. Where a film is very thin, poikilocytosis tends to be eliminated, leaving red cells a uniform round appearance, and, where it is thick, superimposition makes recognition of poikilocytes impossible. Only the part of the film of intermediate thickness with slight overlap of erythrocytes can be used to assess shape.

In the past we have used wet preparations for the quantitative assessment of elliptocytosis (Goodall et al., 1954) and of distortion of erythrocytes in the neonate (Al Hasso et al., 1973); for the latter a completely objective method was devised, but it was felt to be too elaborate and expensive for this study.

As a compromise, three separate simple assessments were made (mainly under $\mathrm{x} 100$ oil lens): first, a count of distorted forms in at least 1,000 red cells in albumin-Ringer Suspension; second, a count of distorted forms in at least 2,000 red cells in intermediately spread fields in one of the three dry films (2 to 10 overlaps per "oil" field), usually that total was seen in 8 to 10 fields; and, third, a subjective assessment based on scanning 50 oil-immersion fields of similar spread in each of the three films (a total of approximately 10,000 cells per film). The wet preparations were counted immediately after being processed: the count on the dry film usually took place soon after; but the subjective assessments were made at variable times up to several months later. The counts were all made by one person (a retired haematologist). without knowledge of the precise source. The subjective assessments were made at random. even for each of the three slides from any one patient.

For control bloods we used only the count on a dried film and the subjective assessment.

\section{RESULTS}

\section{Qualitative Assessment}

The abnormal shapes of erythrocyte found in some patients with S.D.A.T. are shown in Figure 1. Schistocytes are very scanty in contrast to their large numbers in microangiopathic haemolytic anaemia. There was no obvious excess of polychromasia in ordinary films and no distorted forms were polychromatophilic. Reticulocytes were less than $1 \%$ in the two patients with the greatest numbers of distorted red cells. There was no jaundice. Platelets and leucocytes generally showed no abnormality, but 9 of the 50 patients showed slight excess of monocytes and 27 slight lymphopenia (not uncommon in the elderly). Buffy coat smears appeared normal with one exception (Case 33 had no excess of distorted erythrocytes, but showed granulocytes with bizarre nuclei, possibly dysplastic). No excess of granulocyte precursors, no siderocytes, no sideroblasts and no periodic acid-Schiff positive erythrocytes or erythroblasts were seen in any patient. The absence of erythroblasts, Howell-Jolly bodies and target cells is against hyposplenism also eliminated by interference microscopy (Al Hasso et al., 1973)

\section{Quantitative Assessment}

Tabulated data on the patients are given in Appendix 1. Counts on dried films are given in Appendix 2 ( $a$ and $b$ ) with scores of distorted cells corrected to a total of 2,000 erythrocytes. 


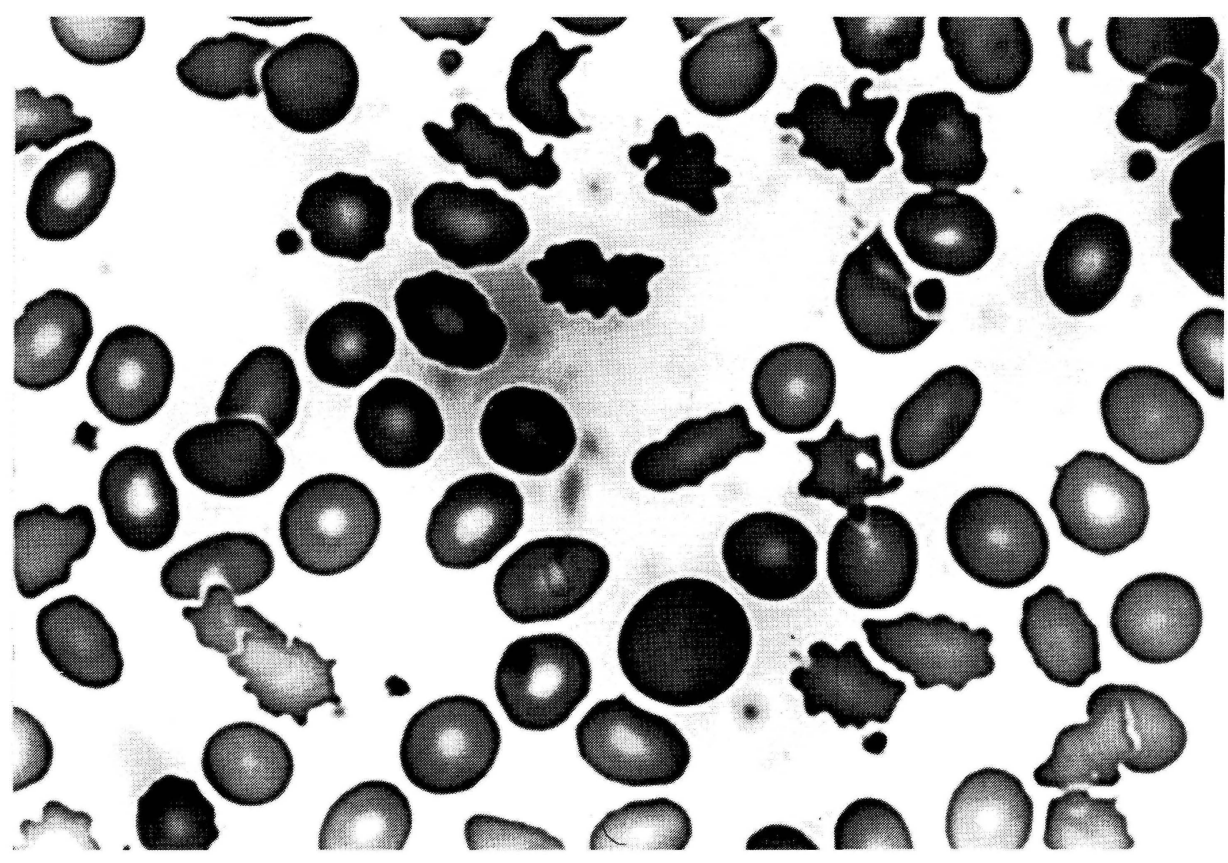

Figure 1. Blood film. Romanowsky stain. magnification X 1.35(). Irregular poikilocytosis with obvious spikes (usually known as acanthocytes, but better described as spur cells), one tiny schistocyte and one giant erythrocyte. Woman aged 82: Hb 12.1G/dl. M.C.V. 81.2fl.: count on this film showed $15.9 \%$ of distorted red cells $(382$ in 2.068$)$.

\section{The Percentage of Irregularly Distorted Erythrocytes}

The percentage of irregularly distorted erythrocytes are shown in Table 1.

Subjective Assessment of Distorted Forms in S.D.A.T. Patients and Controls (based on 3 films from each)

The criterion used for positivity in this assessment was that the slides were scored as positive if, as on routine haematological screening, the observer would have alerted the clinician to the distortion and the need to eliminate such possible causes as hypothyroidism, renal diseases, mechanical damage to the erythrocytes or drug-induced haemolysis.

\section{Patients}

Films from seven cases scored positive ( 6 on all 3 films, one in 2 of the 3 films, the third being borderline; this woman had the smallest score among the positives on wet and dry counts -2.2 and $2.4 \%$ respectively). All seven had counts $>2 \%$ on quantitative assessments. A further five patients showed smaller numbers of spiked erythrocytes; all had counts below $2 \%$ - regarded as equivocal.

\section{Controls}

Five showed definite excess of distorted forms in all three films. (See Table 2). All five had counts of greater than $2 \%$ distorted cells on the formal counts. Seven showed an equivocal appearance - their counts ranged from 0.8 to $1.9 \%$. 
Table 1. Nos. of cases showing different percentages of irregularly distorted erythrocytes.

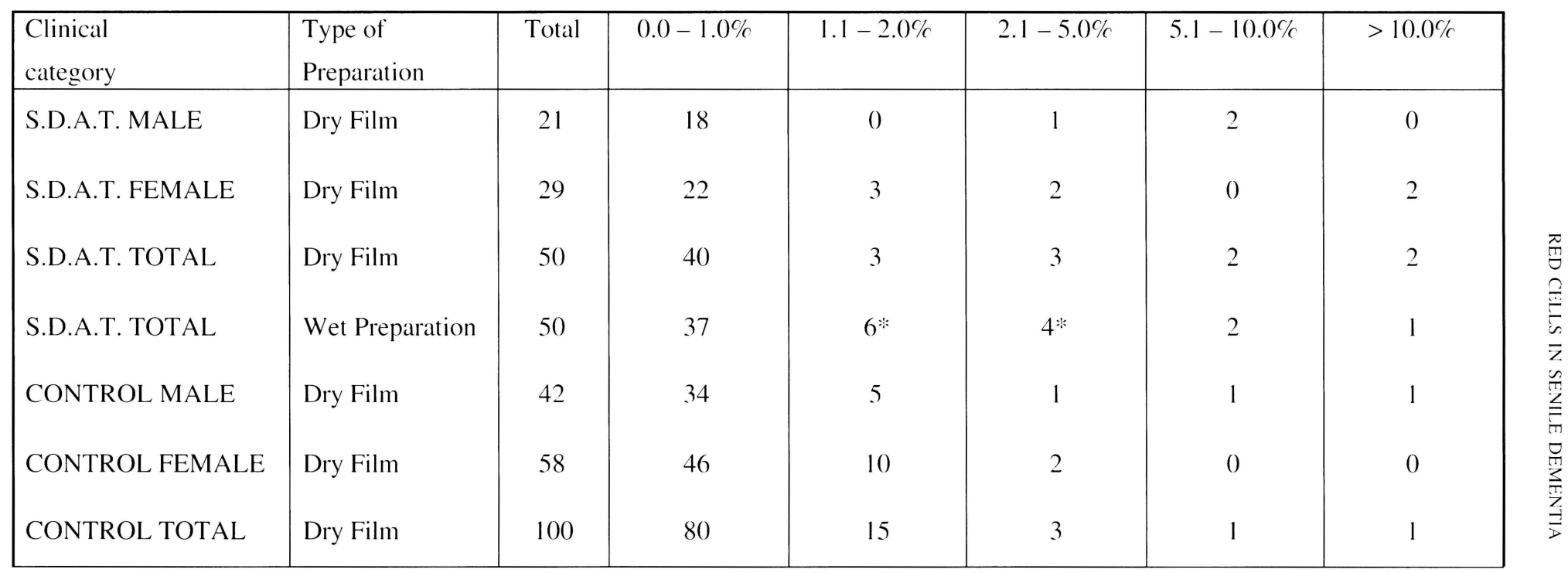

* These slightly higher numbers were to some degree due to crenation in earlier cases before the preparations were ringed with soft vaseline. 
Table 2. Positive control patients

\begin{tabular}{|l|l|l|l|}
\hline Sex & \% Distorted & Other Blood Findings & Clinical Features \\
\hline F & 2.2 & $\begin{array}{l}\text { Numerous crenated red } \\
\text { cells (not uncommon } \\
\text { after thrombolytic } \\
\text { therapy) }\end{array}$ & $\begin{array}{l}\text { Myocardial Infarction. } \\
\text { Thrombolytic Therapy. }\end{array}$ \\
\hline M & 2.7 & $\begin{array}{l}\text { Microangiopathic damage } \\
\text { to red cells. } \\
\text { Schistocytes }\end{array}$ & $\begin{array}{l}\text { Rupture of Abdominal } \\
\text { Aortic Aneurysm. } \\
\text { Postoperative. }\end{array}$ \\
\hline F & 3.6 & $\begin{array}{l}\text { Numerous spiked forms - } \\
\text { may be "spur" cells }\end{array}$ & $\begin{array}{l}\text { Cirrhosis of the liver. } \\
\text { Haematemesis. Bleeding } \\
\text { piles. }\end{array}$ \\
\hline M & 5.5 & $\begin{array}{l}\text { Microangiopathic damage } \\
\text { to red cells. } \\
\text { Schistocytes. Crenation }\end{array}$ & $\begin{array}{l}\text { Terminal carcinoma of } \\
\text { Bronchus. Hemiplegia. } \\
\text { Numerous spiked red } \\
\text { cells. A few giant } \\
\text { erythrocytes. }\end{array}$ \\
\hline D & 19.2 & $\begin{array}{l}\text { Fracturc of Neck of } \\
\text { Femur. } \\
\text { Perioperative } \\
\text { Confusion. Long-term } \\
\text { Significant Memory }\end{array}$ \\
\hline
\end{tabular}

* This patient may have early S.D.A.T., although at present he has a problem only with memory.

\section{Control patients with possibly relevant history}

In the 80 control patients with counts of distorted cells less than $1 \%$ there was one case each of S.D.A.T., vascular dementia, late Down's Syndrome and Korsakoff"s psychosis. One woman, whose count was $1.8 \%$ has suspicious films on subjective assessment; on follow-up she has been found to be attending a clinic for Memory Impairment (Dr. M. McMurdo) and may well have early S.D.A.T.

To sum up the results of counts and microscopical assessment: there appear to be a minority of S.D.A.T. patients with significant distortion of the erythrocytes; distortion in control patients can be accounted for; there appears to be a group with borderline findings which will require more discriminating techniques for valid resolution. Distortion was not related to age; it was associated with marginally low haemoglobin level and 
mean cell volume. All controls without serious disease and with normal blood counts had counts of distorted cells less than $2 \%$.

\section{Direct Coombs Tests}

Direct Coombs Tests were done to exclude coating of cells with immunoglobulins. All are negative.

\section{$A B O$ and Rhesus Blood Groups}

$\mathrm{ABO}$ and Rhesus blood groups were checked in relation to the above. There is a slight excess of Group $\mathrm{O}$ in patients with distorted red cells ( 6 of 7 ) and the control patient with a memory defect and 19.2\% distorted cells is of the same group. Also 4 of the 5 equivocal cases are Gp. O. Many more will have to be examined for a valid assessment. There is no general evidence of McLeod blood type.

\section{Immune Staining for $\beta$-Amyloid Protein}

Immune staining for $\beta$-Amyloid protein on films from the four patients with most pronounced distortion gave a negative result.

\section{DISCUSSION}

The finding of unexplained irregular poikilocytosis with spiked forms in 7 of 50 patients with established S.D.A.T. complements the random finding of such changes in routine haematological screening (Goodall et al., 1991) and suggests a possible relationship. At present we prefer the term irregular or spiked poikilocyte to the more specific acanthocyte (of abetalipoproteinaemia) or spur cell (of liver disease). The spikes of the acanthocyte are much sharper - more thorn-like. The distortion of the S.D.A.T. patients much more resembles that seen in occasional cases of myelodysplasia than of other groups. However, we do not wish to be drawn into a semantic argument about these bizarre shapes.

\section{Statistical Evaluation (See Appendix 2, A, B and C).}

The results of statistical analysis do not give a definite answer. They lend slight support for the possible relationship between distorted red cells and S.D.A.T. and the degree of skewness of the results on the patients points to the possibility that those with S.D.A.T. and distorted cells constitute a special group.

Thus the presence of spiked red cells in the absence of other known causes must raise the possibility of S.D.A.T. Obviously, however, although such cells may give supporting evidence for the diagnosis of S.D.A.T., their absence is not of exclusive significance. However, the finding should not be lightly dismissed as a morphological curiosity, because it may have both practical and theoretical importance. Although there does not at present appear to be any immediate value in the identification of this red cell anomaly in known cases of S.D.A.T., its presence in undiagnosed patients with loss of memory might serve to define a group suitable for pre-emptive medication with various nutritional substances (Evans, 1986), including neurotransmitter precursors (McEntee and Crook, 1990; Crook et al., 1991). This view is encouraged by the knowledge that one of the three cases already demonstrated (Goodall et al., 1991) was known to have distorted red cells years before she became demented and our control patient in the present 
investigation who was found to have numerous spiked erythrocytes, has significant impairment of memory. There is also a patient with smaller number of spiked forms attending a memory clinic. To sum up this aspect, morphological examination of the erythrocytes may have a modest role in the "longitudinal diagnosis of memory disorders" (Brayne and Calloway, 1988; O'Neill et al., 1992).

We are aware that distorted red cells are found more frequently in the elderly than in young adults during haematological screening, but it is only by careful long-term followup that the significance of this can be assessed.

Investigation of the molecular basis of the erythrocytic distortion may help the understanding of the molecular pathology of S.D.A.T. One idea, that the distortion may be due to coating with $\beta$-amyloid protein or immune globulins (as with cryoglobulins) is not supported by immunological staining or the Direct Coombs Test. The type of distortion and dearth of schistocytes are against microangiopathic damage from $\beta$ amyloid angiopathy (Hauw et al., 1991).

Myelodysplasia may lead to erythrocytic distortion similar to that in Alzheimer's disease. Thus, although there is no obvious sign of myelodysplasia, the demonstration of clonality by genetic techniques will be needed to eliminate a latent myelodysplastic process. The S.D.A.T. and myelodysplastic cases both show occasional giant erythrocytes. Such cells and the multinucleate erythroblasts from which they are derived have many causes (Goodall, 1970; Lewis and Verwilghen, 1972); a defect of cell membrane synthesis may underlie the morphological manifestation.

A major field of research on Alzheimer's disease is the study of glucose metabolism of nerve cells in vitro and in vivo. Techniques are frequently invasive, involving the operative collection of nerve cells at brain biopsy (Bowen and Davison, 1986) or the monitoring of glucose, lactate, oxygen and carbon dioxide in blood from femoral artery and jugular bulb (Hoyer, 1991). The inter-relationships between the glycolytic enzymes in brain, blood and muscle are very complex (Paglia 1991), but even in the absence of haemolysis, an investigation of the glycolytic enzymes in the erythrocytes in Alzheimer patients might be an indirect way of assessing their glucose metabolism.

There are no obvious differences in the clinical features between our patients with distorted red cells and those without. One of the patients previously reported (Goodall et al., 1991) with acanthocytosis was younger than the others and his mother also had dementia and distorted red cells; in addition, he and the other male case previously investigated (Goodall et al., 1991) had nutritional deficiencies; yet correction of these made no difference to the distortion of the red cells. The two groups (distorted and nondistorted) are of similar age. There is no preponderance of either sec; thus the McLeod blood type (Winer et al., 1977; Symmons et al., 1979) is excluded. We have not enough data on which to compare with the rare Woronets trait (Beutler et al., 1980).

Also, in relation to the clinical features, none of the conditions outlined in the Introduction are present and there are no localising neurological signs. Thus the acanthocytosis of S.D.A.T. is an entity distinct from abetalipoproteinaemic and normolipoproteinaemic acanthocytosis with degenerative neuropathies. These constitute a rare but complex, heterogeneous group. The first patients studied had acanthocytosis secondary to a recessively inherited failure to absorb fats and consequent abetalipoproteinaemia; they had retinopathy and ataxia but no dementia; their parents, typically consanguinous, had normal lipid levels (Salt et al., 1960). A second, distinct alipoproteinaemic syndrome with acanthocytosis, but usually less severe neural defects, has been shown to 
be due to homozygosity in families with dominant hypolipoproteinaemia (Illingworth $e t$ al., 1980). The difference in these two groups has been confirmed at the molecular, genetic level (Ross et al., 1988). It should also be remembered that some of the secondary effects of these genetic disorders can be reduced by supplements e.g.. of Vitamin $E^{34}$.

The normolipoproteinaemic patients with acanthocytosis and neural defects are even more complex. Broadly, they can be divided into three groups: those with typical choreoathetosis syndrome (Estes et al., 1967; Critchley et al., 1970; Aminoff, 1972; Serra et al., 1986; Villegas, 1987) those related to anomalies of the Kell blood group (X-linked) (Winer et al., 1977; Symmons et al., 1979; Franke et al., 1985; De Saint-Basile et al., 1988); and those with additional clinical and metabolic abnormalities (Spitz et al., 1985; Mukoyama et al., 1986). Inheritance may be recessive or dominant (Villegas et al., 1987). Chemical and physical changes have been found in the red cell membrane (Villegas et al., 1987). There may be mental changes (Critchley et al., 1970; Delecluse et al., 1991). These disparate familial cases of acanthocytosis do not offer any obvious explanation for the occurrence of distorted red cells in senile dementia. Similarly it is doubtful if the spiked red cells of hypothyroidism (Wardrop and Hutchison, 1969; Horton et al., 1976) and anorexia nervosa (Mant and Faragher, 1972) give a clue. The great complexity of the biochemical changes underlying the red cell shape in these conditions made us decide not to pursue these matters until we were convinced that the morphological changes might be significant. Finally, however, the possible importance of apolipoprotein E in S.D.A.T. (Scott, 1993; Owen et al., 1994) does appear to point to the need to determine the apolipoprotein E variants in relation to distortion of the red cells in this condition.

ACKNOWLEDGEMENTS

The statistical analysis was carried out by Mrs. E. Irvine. We are indebted to her, to Professor M.J. Pippard, Mr. J.F. King and their staff for helpful co-operation, Dr. J.M. Anderson for useful support, medical and nursing personnel at Royal Dundee Liff Hospital and Ashludie Hospital for help with obtaining specimens, Mr. S.D. MacPherson for the photograph and Mrs. M. Lorimer and Miss G. Bandeen for special secretarial assistance.

\section{REFERENCES}

Al Hasso, A.R.A., Bennet, R.A., Goodall, H. B. (1973). Quantitative aspects of distortion of erythrocytes: an approach to the problem of microangiopathic haemolytic anaemia in infancy. Bibl. Anat., 12, 46-50.

Aminoff, M.J. (1972). Acanthocytosis and neurological disease. Brain, 95, 749-760.

Bassen, F.A., Kornzweig, A.L. (1950). Malformation of the erythrocytes in a case of atypical retinitis pigmentosa. Blood, 5, 381-387.

Bessis, M. (1977). Blood smears reinterpreted. (Translated by G. Brecher). Berlin, Heidelberg, New York, Springer International, Chap. 2B, pp 50-75.

Beutler, E., West, C., Tavassoli, M., Grahn, E. (1980). The Woronets Trait. A new familial erythrocyte anomaly. Blood Cells, 6, 281-287.

Black, D., Kay, J. (1986). Influence of tube type on antiglobulin test. Med. Lab. Sci., 43, 169-173.

Bowen, D.M., Davison, A.N. (1986). Biochemical studies of nerve cells and energy metabolism in Alzheimer Disease. Brit. Med. Bull., 42, 75-80. 
Bowley, A.R., Gordon, I., Ross, D.W. (1984). Computer controlled automated reading of blood groups using microplates. Med. Lab. Sci., 41, 19-25.

Brain, M.C., Dacie, J.V., Hourihane, D.O'B. (1962). Microangiopathic haemoloytic anaemia: the possible role of vascular lesions in pathogenesis. Brit. J. Haemat., 8, 358-374.

Brayne, C., Calloway, P. (1988). Normal ageing, impaired cognitive functions, and senile dementia of Alzheimer type: a continuum. Lancet, 1, 1265-1266.

Critchley, E.M.R., Betts, J.J., Nicholson, J.T., Weatherall, D.J. (1970). Acanthocytosis, normolipoproteinaemia and multiple tics. Postgrade. Med. J., 46, 698-701.

Crook, T.H., Tinklenberg, J. Yesavage, J., Petrie, W., Nunzi, M.G., Massari, D.C. (1991). Effects of phosphatidylserine in age-associated memory impairment. Neurology, 41, 644-649.

De Saint-Basile, G., Bohler, M.C., Fischer, A., Cartron, J., Duffer, J.L., Griscelli, C., Orkin, S.H. (1988). Xp21 DNA microdeletion in a patient with chronic granulomatous disease retinitis pigmentosa, and McLeod phenotype. Hum. Genet., 80, 85-89.

Delecluse, F., Deleval, J., Gerard, J-M., Michotte, A., de Beyl, D.Z. (1991). Frontal impairment and hypoperfusion in neuroacanthosis. Areh. Neurol., 48, 232-234.

Dodge, J.T., Cohen, G., Kayden, H.J., Phillips, G.B. (1967). Peroxidative hemolysis of red blood cells from patients with Abetalipoproteinemia (acanthocytosis). J. Clin. Invest., 46, 357-368.

Estes, J.W., Morley, T.J., Levinc, I.M., Emerson, C.P. (1967). A new hereditary acanthocytosis syndrome. Amer. J. Med., 42, 868-881.

Evans, J.R. (1986) Alzheimer dementia. Some possible mechanisms related to vitamins, trace elements and minerals, suggesting a possible treatment. J. Orthomolec. Med., 1, 249-254.

Franke, U., Ochs, H.D., De Martinville, B., Giacalone, J., Lindgren, V., Disteche, C., Pagon, R.A., Hofker, M.H., Van Ommen, G.J.B., Pearson, P.L., Wedgewood, R.J. (1985). Minor Xp21 chromosome deletion in a male associated with expression of Duchenne muscular dystrophy, chronic granulomatous disease, retinitis pigmentosa and McLeod Syndrome. Am. J. Hum. Genet., 37, 250-257.

Goodall, H.B. (1970). Atypical changes in the bone marrow in acute infections: Part 1: Polyploidy of the erythroblasts in acute infections. In: Clarke, W.J., Howard, E.B., Hackett, P.L. (Eds.). Myeloproliferative Disorders of Animals and Man. U.S. Atomic Energy Commission, Division of Technical Information, pp 314-327.

Goodall, H.B., Hendry, D.W.W., Lawler, S.D., Stephen, S.A. (1954). Data on linkage in man: elliptocytosis and blood groups III. Family 4. Ann. Eugen., 18, 325-327.

Goodall, H.B., McHarg, J.F., Anderson, J.M., Robertson, J. (1991). Acanthocytosis in disparate clinical states - myelodysplasia and Alzheimer's disease. Leukemia Research, 15 (Supplement), 19.

Hauw, J.-J., Duyckaerts, C., Delaere, P. (1991). Alzheimer's disease - amyloid angiopathy. In: S. Duckett (Ed.). The Pathology of the Aging Human Nervous System. London, Lea and Fibiger Philadelphia. Chap. 4, pp 126-127.

Herbert, P.N., Assmann, G., Gotto, A.M. Jr., Frederickson, D.S. (1983). Familial lipoprotein deficiency. Abetalipoproteinaemia, hypolipoproteinaemia and Tangier disease. In: Stanbury, J.B., Wyngaarden, J.B., Frederickson, D.S. et al. (Eds.). The Metabolic Basis of Inherited Disease, 5th Ed. New York, McGraw-Hill, p 589.

Horton, L., Coburn, R.J., England, J.M., Himsworth, R.L. (1976). The haematology of hypothyroidism. Quart. J. Med., New Series 177, 101-124.

Hoyer, S. (1991). Abnormalitites of glucose metabolism in Alzheimer's disease. Ann. N.Y. Acad. Sci., 640, 53-58.

Illingworth, D.R., Connor, W.E., Buist, N.R.M., Jhaveri, B.M., Lin, D.S., McMurry, M.P. (1979). Sterol balance in Abetalipoproteinemia: studies in a patient with homozygous familial hypobetalipoproteinemia. Metabolism, 28, 1152-1160.

Lewis, S.M., Verwilghen, R.H. (1972). Annotation: dyserythropoiesis and dyserythropoietic anaemias. Brit. J. Haemat., 23, 1-4. 
Mant. M.T., Faragher, B.S. (1972). The haematology of anorexia nervosa. Brit. J. Haemat., 23, 737-749.

McEntee, W.J., Crook, T.H. (1990). Age associated memory impairment. A role for catecholamines. Neurology, 40, 526-530.

Mukoyama, M., Kazui, H.,, Sunohara, N., Yoshuda, M., Nonaka, I., Satoyoshi, E. (1986). Mitochondrial myopathy, encephalopathy, lactic acidosis and stroke-like episodes with acanthocytosis: a clinico-pathological study of a unique case. J. Neurol., 233, 228-232.

O’Neill, D., Surmon, D.J., Wilcock, G.K. (1992). Longitudinal diagnosis of memory disorders. Age and Ageing, 21, 393-397.

Oski, F.A., Nathan, D.G., Sidel, V.W., Diamond, L.K. (1964). Extreme hemolysis and red cell distortion in erythrocyte pyruvate kinase deficiency. 1. Morphology, erythrokinetics and family enzyme studies. N. Engl. J. Med., 270, 1023-1030.

Owen, M., Liddell, M., McGuffin, P. (1994). Alzheimer's disease. An association with apolipoprotein E4 may help unlock the puzzle. Brit. Med. J., 308, 672-673.

Paglia, D.E. (1991). Enzymopathies - Chapter 37. In: Hoffman, R., Benz, E.J. Jr., Shattil, S.J., Furie, B., Cohen, H.J. (Eds.). Hematology - Basic Principles and Practice. New York, Edinburgh, London, Melbourne, Tokyo, Churchill Livingstone, pp 504-513.

Roberts, G.W., Allsop, D., Bruton, C. (1990). The occult aftermath of boxing. J. Neurosurg. Psych., 53, 373-378.

Ross, R.S., Gregg, R.E., Law, S.W., Monge, J.C., Grant, S.M., Higuchi, K., Triche, T.J., Jefferson, J., Brewer, H.B. Jr. (1988). Homozygous hypobetalipoproteinemia: a disease distinct from Abetalipoproteinemia at a molecular level. J. Clin. Invest., 81, 590-595.

Salt, H.B., Wolff, O.H., Lloyd, J.K. et al. (1960). On having no betalipoprotein: a syndrome comprising abetalipoproteinaemia, acanthocytosis and steatorrhoea. Lancet, 2, 325-329.

Scott, J. (1993). Apolipoprotein E and Alzheimer's disease. Lancet, 342, 696.

Serra, S., Xerra, A., Arena, A. (1986). Amyotrophic choreo - acanthocytosis: a new observation in Southern Europe. Acta Neurol. Scand., 73, 481-486.

Smith, J.A., Lonergan, E.T., Sterling, K. (1964). Spur cell anaemia: hemolytic anaemia with red cells resembling acanthocytes in alcoholic cirrhosis. N. Engl. J. Med., 271, 396-398.

Spitz, M.C., Jankovic, J., Killian, J.M. (1985). Familiar tic disorder, parkinisonism, motor neuron disease, and acanthocythosis: a new syndrome. Neurology, 35, 366-370.

Symmons, W.A., Shepherd, C.S., Marsh, W.L., Øyen, R., Shohet, S.B., Linehan, B.J. (1979). Hereditary acanthocytosis associated with the McLeod Phenotype of the Kell Blood Group System. Brit. J. Haemat., 42, 575-583.

Villegas, A., Moscat, J., Vazques, A., Calero, F., Alvarez-Sala, J.L., Artola, S., Espinos, D. (1987). A new family with hereditory choreo-acanthocytosis. Acta haemat., 77, 215-219.

Wardrop, C., Hutchison, H.E. (1969). Red cell shape in hypothyroidism. Lancet, 1, 1243.

Winer, B.M., Marsh, W.L., Taswell, H.F., Galey, W.R. (1977). Haematological changes associated with the McLeod Phenotype of the Kell Blood Group System. Brit. J. Haemat., 36, 219224. 


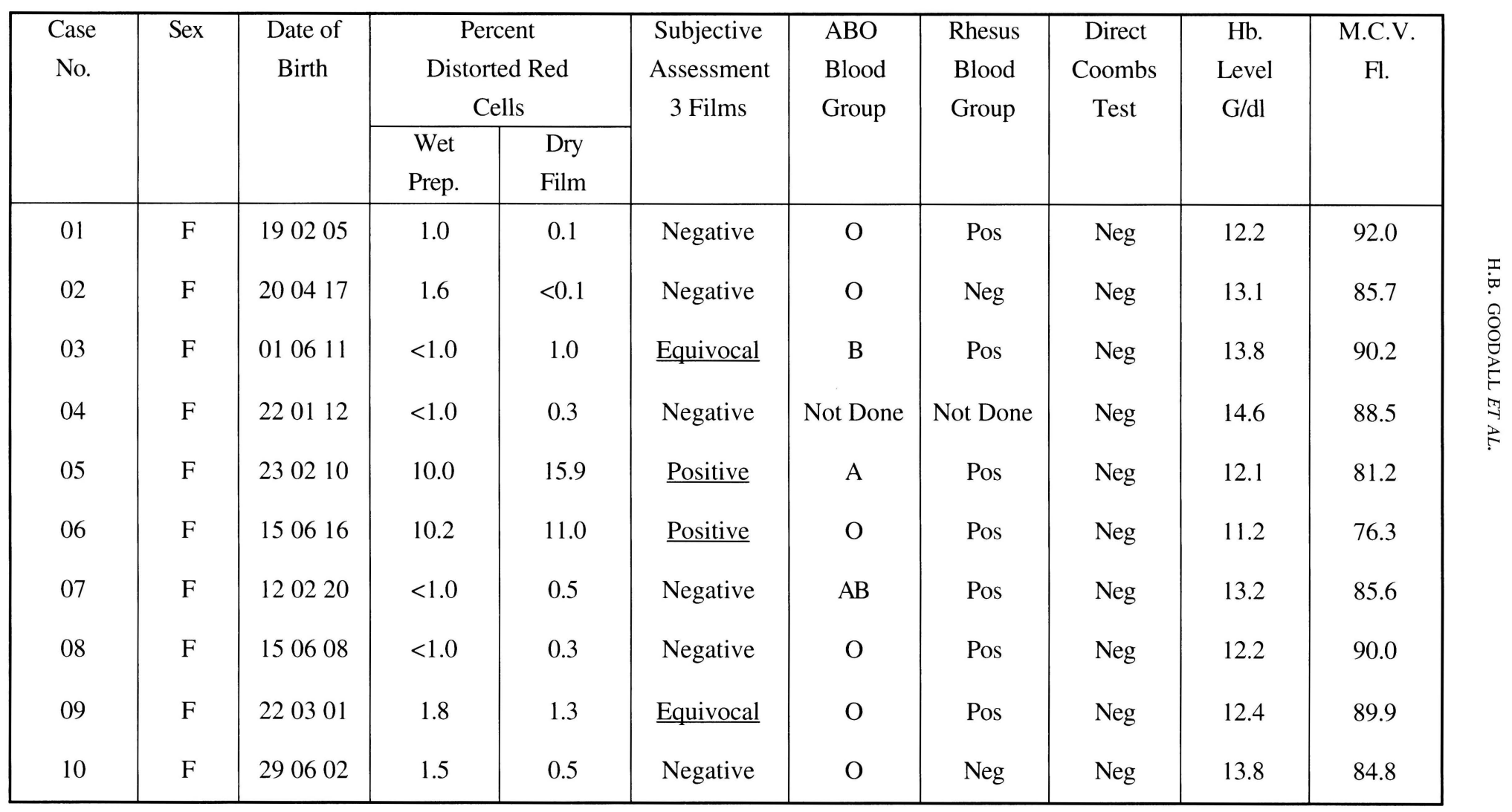




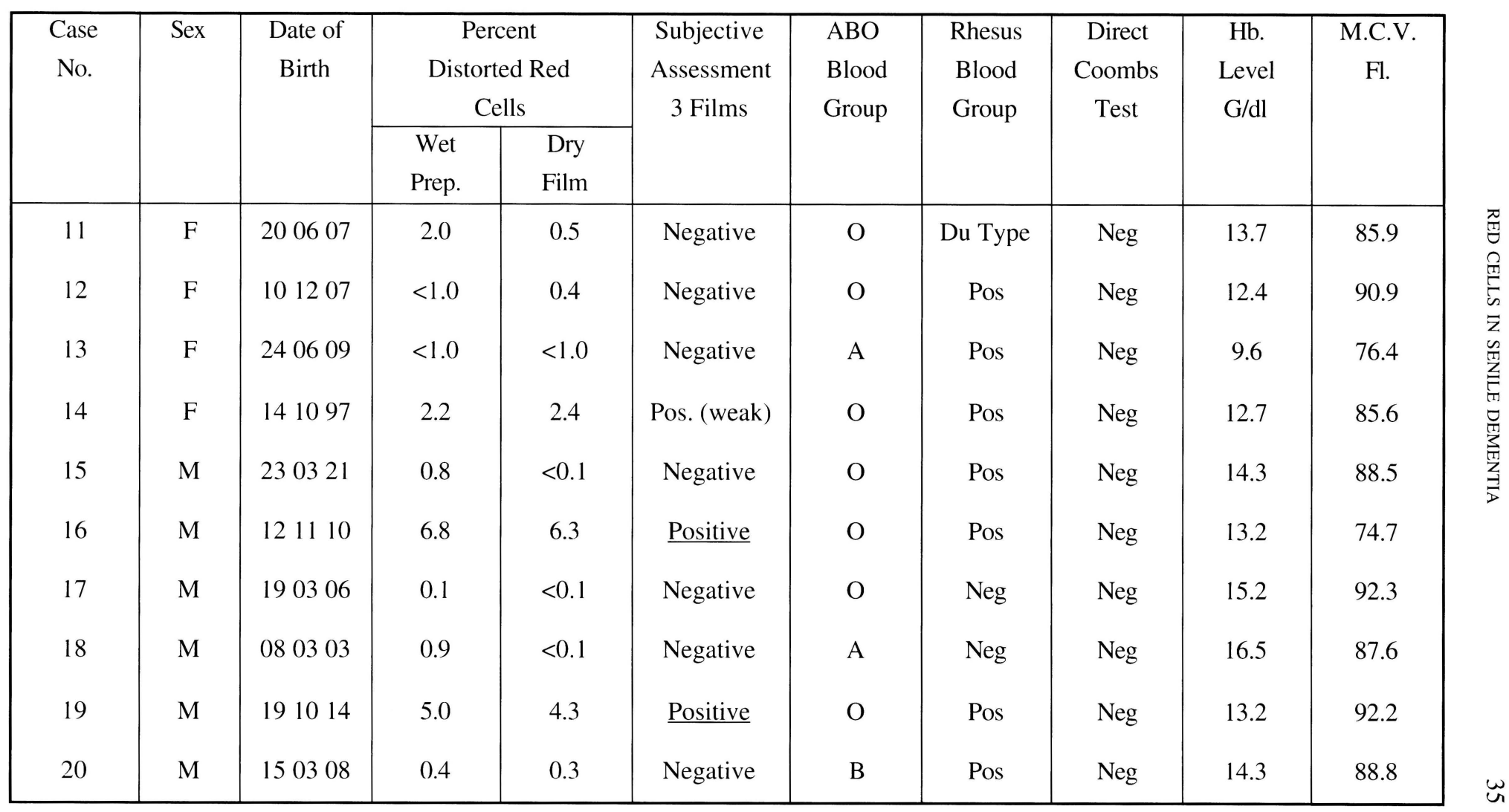




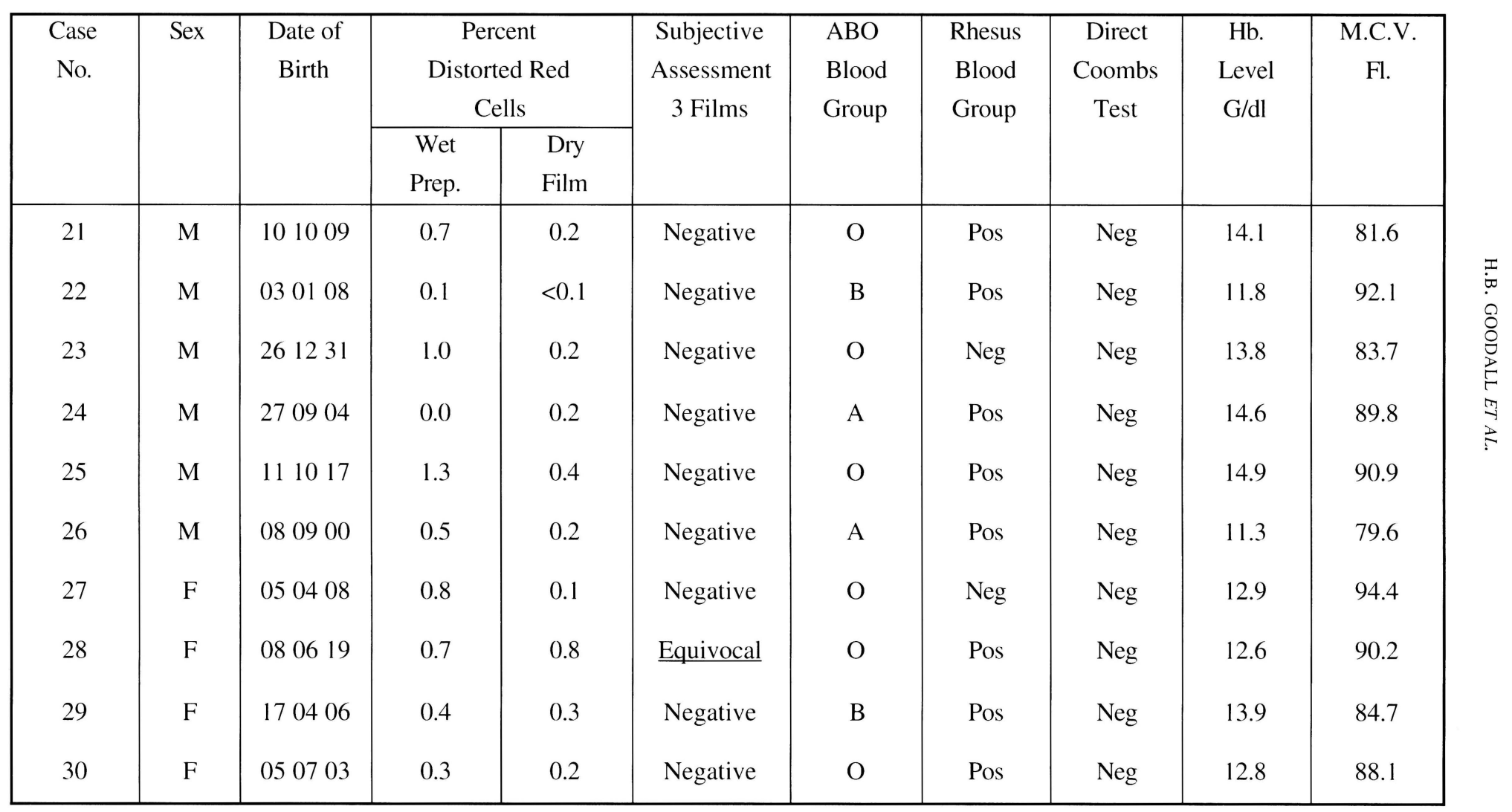




\begin{tabular}{|c|c|c|c|c|c|c|c|c|c|c|}
\hline \multirow[t]{2}{*}{$\begin{array}{c}\text { Case } \\
\text { No. }\end{array}$} & \multirow[t]{2}{*}{ Sex } & \multirow[t]{2}{*}{$\begin{array}{c}\text { Date of } \\
\text { Birth }\end{array}$} & \multicolumn{2}{|c|}{$\begin{array}{c}\text { Percent } \\
\text { Distorted Red } \\
\text { Cells }\end{array}$} & \multirow[t]{2}{*}{$\begin{array}{c}\text { Subjective } \\
\text { Assessment } \\
3 \text { Films }\end{array}$} & \multirow[t]{2}{*}{$\begin{array}{l}\mathrm{ABO} \\
\text { Blood } \\
\text { Group }\end{array}$} & \multirow[t]{2}{*}{$\begin{array}{l}\text { Rhesus } \\
\text { Blood } \\
\text { Group }\end{array}$} & \multirow[t]{2}{*}{$\begin{array}{c}\text { Direct } \\
\text { Coombs } \\
\text { Test }\end{array}$} & \multirow[t]{2}{*}{$\begin{array}{c}\mathrm{Hb} . \\
\text { Level } \\
\mathrm{G} / \mathrm{dl}\end{array}$} & \multirow[t]{2}{*}{$\begin{array}{c}\text { M.C.V } \\
\text { Fl. }\end{array}$} \\
\hline & & & $\begin{array}{l}\text { Wet } \\
\text { Prep. }\end{array}$ & $\begin{array}{l}\text { Dry } \\
\text { Film }\end{array}$ & & & & & & \\
\hline 31 & M & 120320 & 4.0 & 5.4 & Positive & $\mathrm{O}$ & Pos & $\mathrm{Neg}$ & 13.8 & 88.5 \\
\hline 32 & M & 090612 & 0.7 & 0.1 & Negative & A & Pos & $\mathrm{Neg}$ & 13.2 & 87.4 \\
\hline 33 & M & 050817 & 0.3 & $<0.1$ & Negative & $\mathrm{O}$ & $\mathrm{Neg}$ & $\mathrm{Neg}$ & 14.6 & 87.8 \\
\hline 34 & $\mathrm{~F}$ & 240805 & 1.0 & 0.5 & Negative & A & Pos & $\mathrm{Neg}$ & 13.0 & 87.8 \\
\hline 35 & F & 241203 & 0.6 & 1.5 & Equivocal & $\mathrm{O}$ & Neg & $\mathrm{Neg}$ & 13.8 & 89.3 \\
\hline 36 & F & 260807 & 0.6 & 0.3 & Negative & A & Pos & $\mathrm{Neg}$ & 11.2 & 97.3 \\
\hline 37 & F & 051208 & $<1.0$ & 0.2 & Negative & $\mathrm{O}$ & Pos & Neg & 12.6 & 91.2 \\
\hline 38 & F & 120509 & $<0.1$ & 0.4 & Negative & B & $\mathrm{Neg}$ & $\mathrm{Neg}$ & 12.6 & 95.8 \\
\hline 39 & $\mathrm{~F}$ & 260503 & 0.2 & 0.3 & Negative & $\mathrm{O}$ & Pos & $\mathrm{Neg}$ & 12.3 & 85.4 \\
\hline 40 & F & 041024 & 0.2 & 0.2 & Negative & A & $\mathrm{Neg}$ & $\mathrm{Neg}$ & 13.1 & 93.7 \\
\hline
\end{tabular}




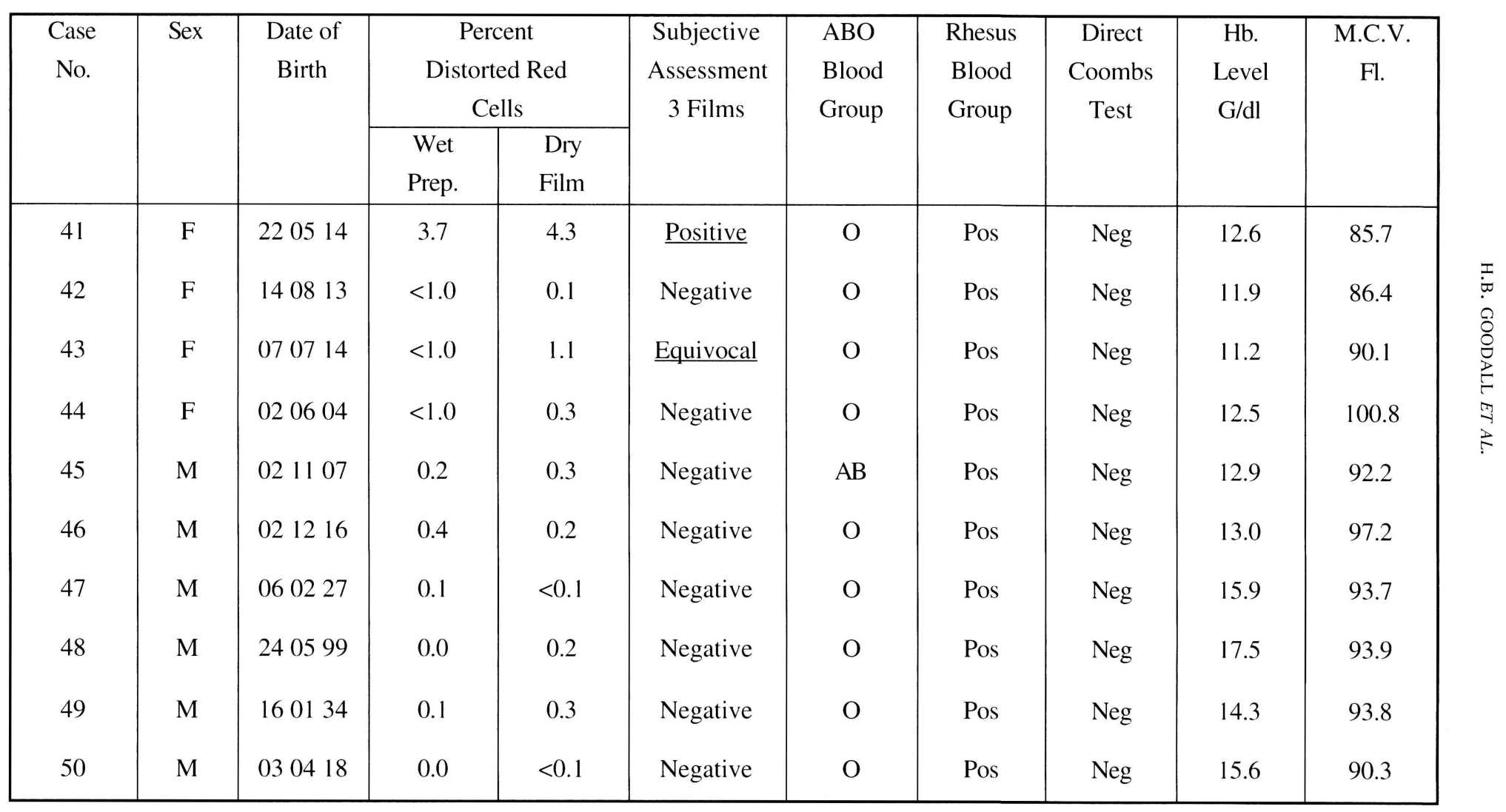


Appendix 2A: Patients

Numbers of irregularly distorted red cells per 2,000 erythrocytes in descending order

\begin{tabular}{|c|c|c|c|}
\hline 1 & 317 & 26 & 6 \\
\hline 2 & 220 & 27 & 5 \\
\hline 3 & 126 & 28 & 5 \\
\hline 4 & 118 & 29 & 5 \\
\hline 5 & 86 & 30 & 4 \\
\hline 6 & 86 & 31 & 4 \\
\hline 7 & 48 & 32 & 4 \\
\hline 8 & 31 & 33 & 4 \\
\hline 9 & 25 & 34 & 4 \\
\hline 10 & 21 & 35 & 4 \\
\hline 11 & 21 & 36 & 4 \\
\hline 12 & 17 & 37 & 3 \\
\hline 13 & 11 & 38 & 3 \\
\hline 14 & 10 & 39 & 2 \\
\hline 15 & 10 & 40 & 2 \\
\hline 16 & 10 & 41 & 2 \\
\hline 17 & 9 & 42 & 1 \\
\hline 18 & 8 & 43 & 1 \\
\hline 19 & 8 & 44 & 1 \\
\hline 20 & 7 & 45 & 1 \\
\hline 21 & 6 & 46 & 1 \\
\hline 22 & 6 & 47 & 1 \\
\hline 23 & 6 & 48 & 1 \\
\hline 24 & 6 & 49 & 1 \\
\hline 25 & 6 & 50 & 1 \\
\hline
\end{tabular}

Note: All the raw counts were based on a total of over 2,000 erythrocytes. The figures were corrected to a total of 2,000 for comparative purposes. 
Appendix 2B: Controls.

Numbers of irregularly distorted cells per 2,000 erythrocytes in descending order.

\begin{tabular}{|c|c|c|c|c|c|c|c|}
\hline$* 1$ & 383 & 26 & 18 & 51 & 7 & 76 & 2 \\
\hline$* 2$ & 110 & 27 & 16 & 52 & 7 & 77 & 2 \\
\hline$* 3$ & 72 & 28 & 16 & 53 & 7 & 78 & 2 \\
\hline$* 4$ & 54 & 29 & 16 & 54 & 7 & 79 & 1 \\
\hline$* 5$ & 45 & 30 & 15 & 55 & 7 & 80 & 1 \\
\hline 6 & 40 & 31 & 15 & 56 & 7 & 81 & 1 \\
\hline 7 & 38 & 32 & 14 & 57 & 6 & 82 & 1 \\
\hline$* 8$ & 35 & 33 & 14 & 58 & 6 & 83 & 1 \\
\hline 9 & 31 & 34 & 14 & 59 & 6 & 84 & 1 \\
\hline 10 & 28 & 35 & 14 & 60 & 6 & 85 & 1 \\
\hline 11 & 26 & 36 & 12 & 61 & 5 & 86 & 1 \\
\hline 12 & 26 & 37 & 12 & 62 & 4 & 87 & 1 \\
\hline 13 & 24 & 38 & 12 & 63 & 4 & 88 & 1 \\
\hline 14 & 24 & 39 & 12 & 64 & 4 & 89 & 1 \\
\hline 15 & 22 & 40 & 11 & 65 & 4 & 90 & 1 \\
\hline 16 & 22 & 41 & 10 & 66 & 4 & 91 & 0 \\
\hline 17 & 22 & 42 & 10 & 67 & 4 & 92 & 0 \\
\hline 18 & 22 & 43 & 10 & 68 & 4 & 93 & 0 \\
\hline 19 & 22 & 44 & 10 & 69 & 3 & 94 & 0 \\
\hline 20 & 21 & 45 & 9 & 70 & 2 & 95 & 0 \\
\hline 21 & 20 & 46 & 8 & 71 & 2 & 96 & 0 \\
\hline 22 & 20 & 47 & 8 & 72 & 2 & 97 & 0 \\
\hline 23 & 18 & 48 & 8 & 73 & 2 & 98 & 0 \\
\hline 24 & 18 & 49 & 8 & 74 & 2 & 99 & 0 \\
\hline 25 & 18 & 50 & 8 & 75 & 2 & 100 & 0 \\
\hline
\end{tabular}

Note: Figures based on the raw counts of over 2,000 cells per case - corrected for comparative purposes.

* All cases marked thus have been eliminated from the statistical analysis, either because they almost certainly have early S.D.A.T., or have other organic diseases often associated with irregular distortion of erythrocytes (See Table 2). 
Appendix 2C: Statistical presentation.

Variable: CELLS SELECT

$($ STATUS $=1)$

(STATUS $=2$ )

CONTROLS

PATIENTS

\begin{tabular}{|l|c|c|}
\hline Sample size & 94 & 50 \\
\hline Average & 9.48936 & 25.78 \\
\hline Median & 7 & 6 \\
\hline Mode & 1 & 1 \\
\hline Variance & 84.8762 & 3396.58 \\
\hline Standard deviation & 9.21283 & 58.2802 \\
\hline Standard error & 0.950231 & 8.24207 \\
\hline Minimum & 0 & 1 \\
\hline Maximum & 40 & 317 \\
\hline Range & 40 & 316 \\
\hline Lower quartile & 2 & 3 \\
\hline Upper quartile & 15 & 11 \\
\hline Interquartile range & 13 & 8.63821 \\
\hline Skewness & 1.11196 & 10.5026 \\
\hline Standardized skewness & 4.40126 & 20.8573 \\
\hline Kurtosis & 0.836503 & \\
\hline Standardized kurtosis & 1.65549 & 8504 \\
\hline
\end{tabular}

Comparison of two samples

Sample 1: CELLS SELECT (STATUS=1)

Sample 2: CELLS SELECT (STATUS=2)

Test based on: Pairs

Average rank of first group $=71.6702$ based on 94 values.

Average rank of second group $=74.06$ based on 50 values.

Large sample test statistic $\mathrm{Z}=0.326141$

Two-tailed probability of equalling or exceeding $Z=0.744314 *$

Note: 144 total observations.

* These calculations are comparible with $t$-test.

Kolmogorov-Smirnov Two-Sample Test*

Sample 1: CELLS SELECT (STATUS=1)

Sample 2: CELLS SELECT (STATUS=2)

Estimated overall statistic DN $=0.234043$

Approximate significance level $=0.559932$

*These calculations are comparable with $t$-test. 


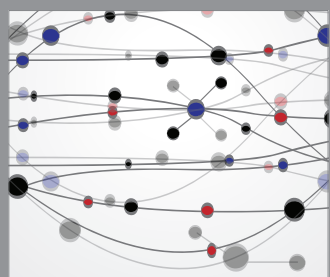

The Scientific World Journal
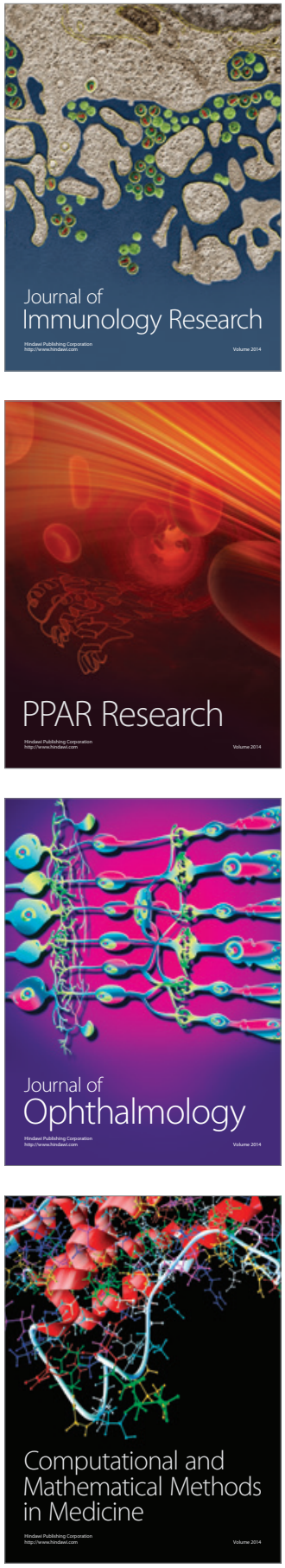

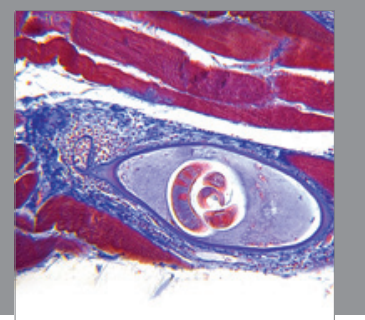

Gastroenterology

Research and Practice
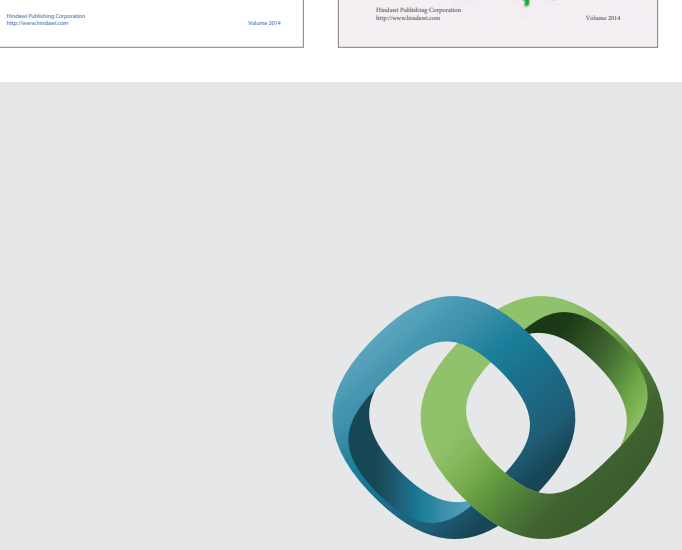

\section{Hindawi}

Submit your manuscripts at

http://www.hindawi.com
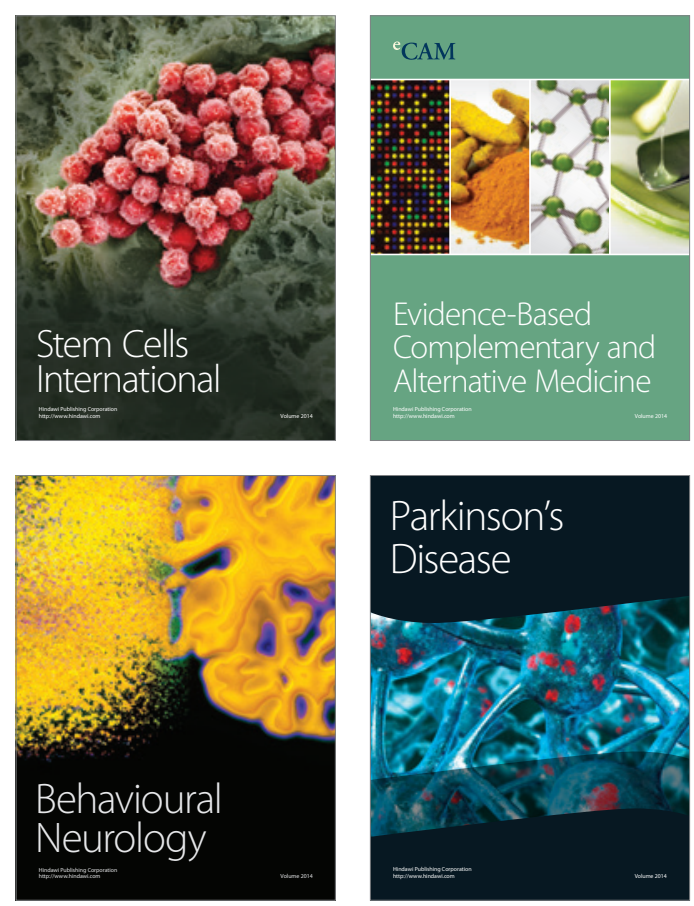

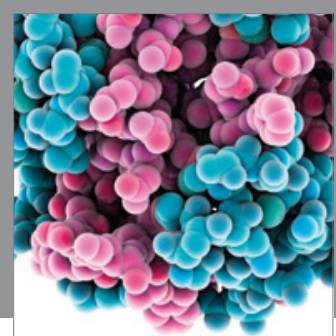

Journal of
Diabetes Research

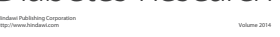

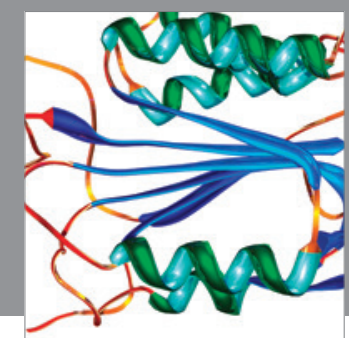

Disease Markers
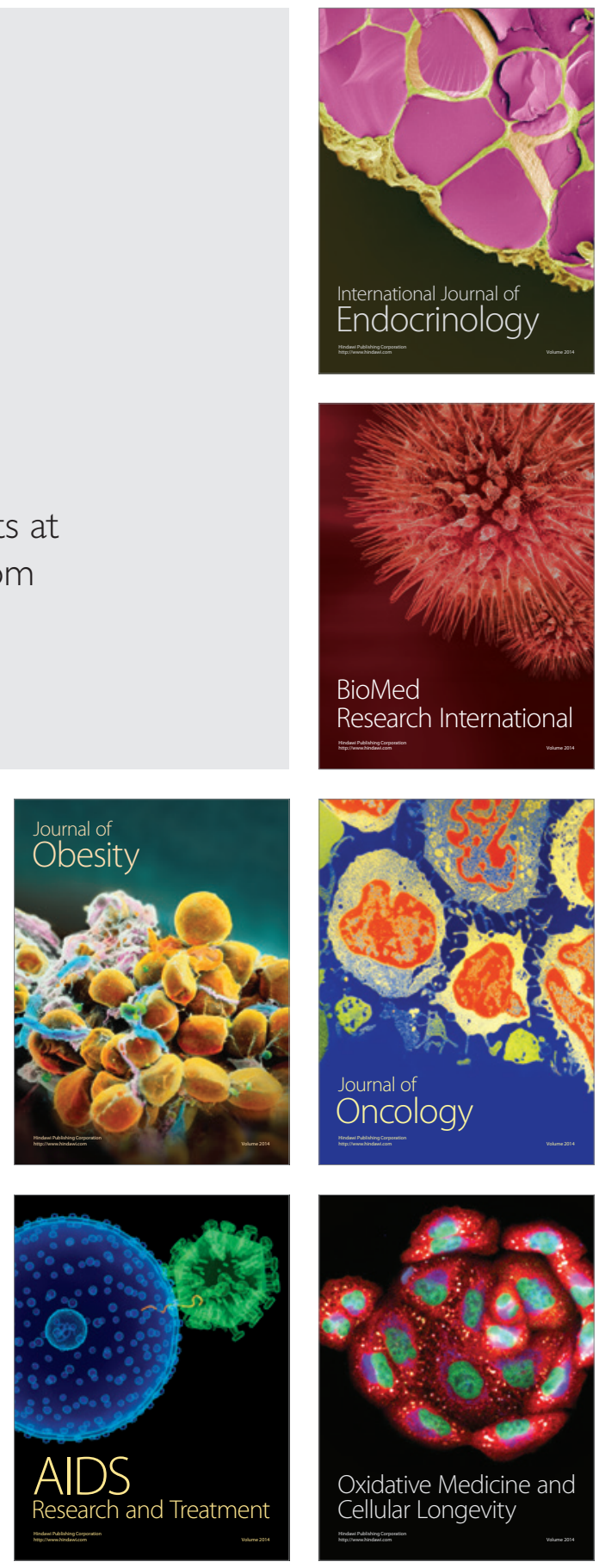